\title{
【悯田琴次先生古稀記念淪文】
}

\section{S. SHIGENO, M.D.: CHRONIC OTITIS MEDIA AND SCLEROSIS OF THE TENPORAL BONE}

\section{慢性中耳炎と溉頭骨の硬化 大分跌道痛院耳悬咽喉科医長 \\ 重野镍军}

\section{緒霉}

慢性中耳炎方，硬化した側頭骨に見られることか ら，慢性中耳炎は蜂巢隔壁の硬化を来し，遂にKompakt な側頭骨を形成するものとの考光が向一般 に根強く信ぜられている。

慢性中耳炎患者のレ線像を見ると，ほとんど蜂笨 抑制状態にあることは事実であるが，慢性非耳炎の 中耳蜂笨の骨壁は，Sklerosierung を起するのてな く，化膿性の炎症は粘膜内に止るものがあつて，著 者は先に，“慢性中耳炎と Pneumatisations-hemmung"の論交を会報に発表した。

文骨壁に吸仅所見は見られるが，これは粘膜の变 化を関係のない・生理的な含気腔の Umbauprozess であることる附言した。䗋巢発育抑制例に慢性の中 耳炎は起るが，慢性中耳慈によつては蜂巢の Sklerosierung 来すおのではない事主証した。この 関係を更に磪実に証明するには慢性中耳炎䍜患前後 のレ線像を比較権察するより他に力法はないのであ る.然しこれは極めて团難なことであつて未だ文献 を見ない。

長大では中耳炎の既往厢を持たない生啳すケ月の 乳児を撰び蜂案の発青状態を每年レ線的に観察して いるが，その中て 2 例がその途中にたまたま慢性中 耳炎に䍜患したのて，その前後の蜂笨のレ線像を比 較することが出来た。この患者には更に手術を行つ て，組織学的にも観察することお出来たのて，この 㑡頭骨の慢性炎症問題に責重なる資料を提供するす のとして、こょに報告する次第である。

症例

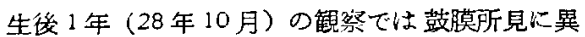
9-85

\begin{tabular}{|c|c|c|c|}
\hline L線撮影牛月 & 局所所見 & R & \\
\hline 28年10月 & 鼓膜正常 & 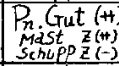 & 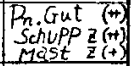 \\
\hline 29年10月 & 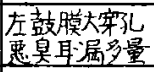 & 稍々拡大 & 稍々摭大 \\
\hline 30年2月 & 左半根活街施行 & 殆 $\alpha{ }^{\prime \prime}$ 同大 & 骀んど同大 \\
\hline 30年10月 & & & op Höhle \\
\hline
\end{tabular}

常なく，レ線所見では右側に䗋倮の発蕉を示す明る

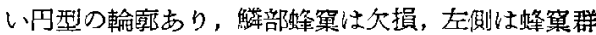
の発育は覀いが，解部䗋策群の発育は良好である。 更に1年娞に（29年10月）左漫性化膿性中耳炎を 発病したので，4 ケ月後 (30年2月)に手術を行つ た、結核性であることを碇めた。

手術所見は，蜂倮の発育は比輘的良好で中央に乾 酷樣塊あり，周国蜂菒壁脆弱にして，粘膜は肉苯様 に腫脹。

組織所見は，上皮は cubisch 又は扁平で腔内に は分速物の塊あり，上皮は一部破壊されている部分 も認めら机る。

上皮下菑は一般に各蜂架々もに厚く，なかには厚 い myxomatős な組織が存在しているものむおる。

上皮直下には円型細胞の浸潤の栖めて強い部分る 認められるが，何れむ浅い層の間であつて梁層には ほとんど浸潤が認められない，myxomatösな組織 には，小，中円型細胞，組織球，星芒状細胞等が認 められ，父毛細血管も多い，血管周因に注他の部分 と比較して細胞浸潤が特に強く認められる。

周团の骨組䢂は総て幼若であつて, Ostesblasten に上万骨の堌殖所見はほとんど㤎められない，で 
反して，Osteoklasten による生理的な lacunäre Resorption の像が散見され，筧万骨の吸收所見の 万が著明である如く見られる，本例では炎症は結核 性であつたが，慢性资症の存在によつて蜂巢の登育 は停止せ才，害万淮展の所見が線的にも組織学的 にも認められた（第1図）。

II浦田国淩 4 才

\begin{tabular}{|c|c|c|c|}
\hline \multirow{2}{*}{ し、早梏要年日 } & \multirow{2}{*}{ 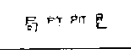 } & $1 \quad \pi$ & 称是 \\
\hline & & R & L \\
\hline 27年16月 & 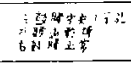 & 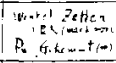 & 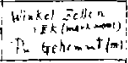 \\
\hline$\angle 8+2$ म & 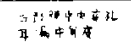 & & \\
\hline $28 \div 1 \mathrm{AB}$ & 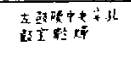 & $\begin{array}{c}\text { zellen wertest } \\
1-1\end{array}$ & $\begin{array}{c}\text { Fellen Warkstum } \\
1-\end{array}$ \\
\hline \multicolumn{4}{|c|}{ 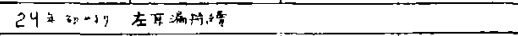 } \\
\hline $294 \quad 108$ & 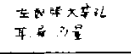 & Fillen $\operatorname{lin}_{1-1}$ & 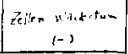 \\
\hline 30 年 2 月 & 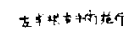 & 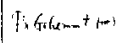 & 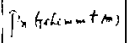 \\
\hline $309 \quad 101$ & & 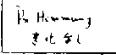 & $\begin{array}{c}P_{x} \text { Hrammg } \\
y+1\end{array}$ \\
\hline
\end{tabular}

27 年 10 月左耳鼓膜に小穿孔、レ線では两側とも 蜂璂を認めら机ない，28年 2 月より左耳漏，察孔 㹡大, 它の後耳漏持続. 29 年 10 月左耳手術. 28 年 10月，29年10月，2回のレ楾撮影せるも両側䗋集 の発育は認められぬる手術により小なる Antrum の周囲に小䗋案群を認めた。

組織学的に摘出骨片内には小蜂窠を多数認め，上 皮は cubisch 又は扁平で，前例と同様上皮下には 円型細胞の浸潤を認るるが，深算に行く々之等の細 胞浸潤はほとんど認められない，挖内には分泌物が 認めら礼，一部上皮は破溒されて腔内との細胞の斿 走している像が見られる。この例にも胎生期組織が 見られる，胎生期組織の骨壁と接した炎症所見のな い部分に於て，骨の吸收所見を著明に認めるのに反 して，骨の増殖所見はほとんど見る事が出来ない， 本例は強度の蜂策発䯩抑制例炏慢性炎症が合併した むのと思机机る例て古る. 鼓膜小等孔の存在は炎症 の経過を意味しているが，跬側も高度の Pneumatisations-hemmung の存在することから，患側の Pneumaisation る体質的なものと思われる. 然し 組織学的には炎症による埄笨腔緶小の所見は認めら

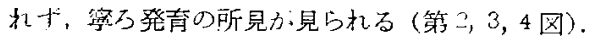

考按

炎症の持続により蜂䆞の骨壁が増殖し，蜂巢を埋 めつくすとの考方力は前述の如く，慢性中耳炎の患 者のレ線像ぶ流とんど硬化の状態にむる事実によつ ているむのであつて，組織学的にはそらした証明は 何もない. 㕛そらでないといらはつきりした証明も Zirgler の簡単な研究以外にはなからた.この点に 就いて著者はさきの発表に於いて組織学的に炎症に より側頭骨硬化の起らないことを立証したのであつ た.レ線的には Knick u. Witte の報告その他多 数があるが，総て中耳炎罪患後のレ線像を観察の対 象としたものである.慢性中耳炎霍患前の乙線像と その後のレ線像とを比跤検討することによつて，は じぬてこの炎症が Pneumatisations-hemmung の 原因となるか否かを明䐲に判定することが出来るは ずである。

幸にこっに以上の如き 2 症例を得たのであるが， 乙線的に既に䍜患前 1 例恃中等度の，他の 1 例恃著 明なるPn.-hemmung の所見を呈していたものであ るが，曼性炎症によつて Pn.-hemmung を来たす のでない，1例では却つて発育することを確め，

Pn-hemmung の例に慢性炎症の来つたものである ことを゙レ線的に証明したものである。

更に組織学的にも，所謂 Sklerosierung の所見 はなく，密ろ lacunäre Resorption の所見の方が 著明で南ることが見られ，寧万 Pneumatisation としては俆々ではあるが発育していると見做さる可 き所見であることを明か比した。

後藤教授及び小林は正常蜂笨発育を次の 3 期に分 類している.

$\begin{array}{lll}\text { 第一発育期 } & \text { 基本的空腔形成期 } & \text { (生後 } 1 \text { 年迄). } \\ \text { 第二発育期 } & \text { 蜂㔬完成期 } & \text { (青春期迄) } \\ \text { 第三発育期 } & \text { 含気化充実期 } & \text { (終 生) }\end{array}$

この分類によれば，この 2 症例は第二発育期の初 めにあたるものであつて，求心性，啩性に強い発 育が行われる時期である. 若し Hemmung があれ ば判定され得る時期である。この意味からこの 2 症 例ではレ線的な判定を信頉出来る。儿線的にも炎症 が Pneumatisations-hemmung の成因とは考光ら れない事を示している。

組織学的には小䗋菓が多数見られ，胎生期組織の， 
线存である myxomatose Gewebe が上皮より離 れた隔壁間に存在している。この部分には上皮值下 に見る様な円型細胞の唚潤は梁层に行くに従つて減 少し，ほとんど認められなくなる。唯血管周囲にの み細胞の浸潤が認められる。

斯る部分に接する骨壁似は炎店性の骨の增殖，吸 收，glatte Resorption の像は全然認められす，它に 反して Osteoklastenを伴つた骨の生理的吸収所見 lacunäre Resorption $の$ 像及び Osteoblasten $k$ よる骨の増殖所見が認められる.

幼坚に於ける䗋巢壁の生理的骨吸收，增殖所見 は，成人に比して遥かに盛んである．又幼児に於て の骨吸収所見は，增殖所見よりは遥かに強く見られ る.この2症例に於ても吸收所見は増殖所見より趛 かに強い.これは含気化の進展を綋味しているもの である．然しこの両機転とも粘膜の变化と江全く関 俰なく，生理的な合気化活動がな敃われている事 を示立所見である。

結論

2 才，4才の幼罗の2症例汸於て，慢性中耳炎漼
患前後の数年のレ線写真と，その手術持摘出墂本の

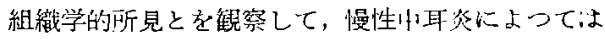
側頭骨の硬化は起るものではない事を重权て証明し た。

1) Witmaack: 文 献 she pneumatisation des Schläfen-bein 1918. 2) Knick u. Witte: Arch. f. O. Bd, 119, 1928. 3) Ziegler: Zeit. f. H.N.O. Bd. 39, 1936. 4)

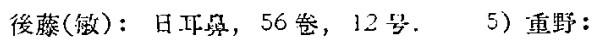
日耳贸，58卷，5兴. 6) Mittermaier: Zschr. f. H. usw. H. Bd. $42,1937$.

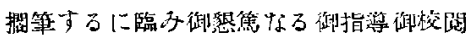
賜わりし恩師後藤敏郎教授に深渐政しま I （原稿到萺＝昭和31.3.22日） 


\section{重 野 論 改附 䝙}

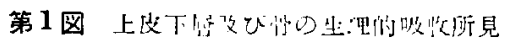

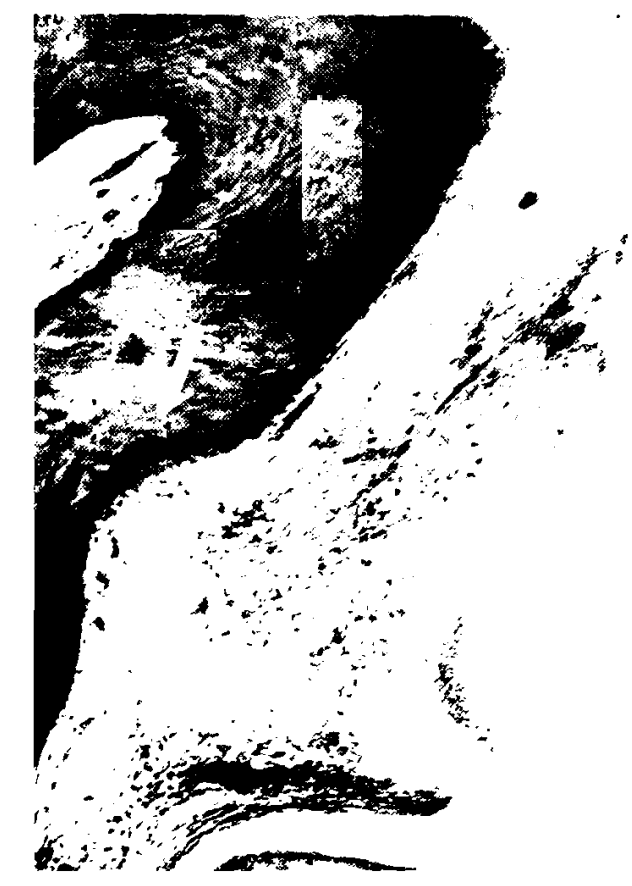

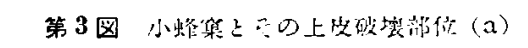

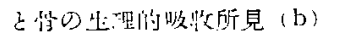

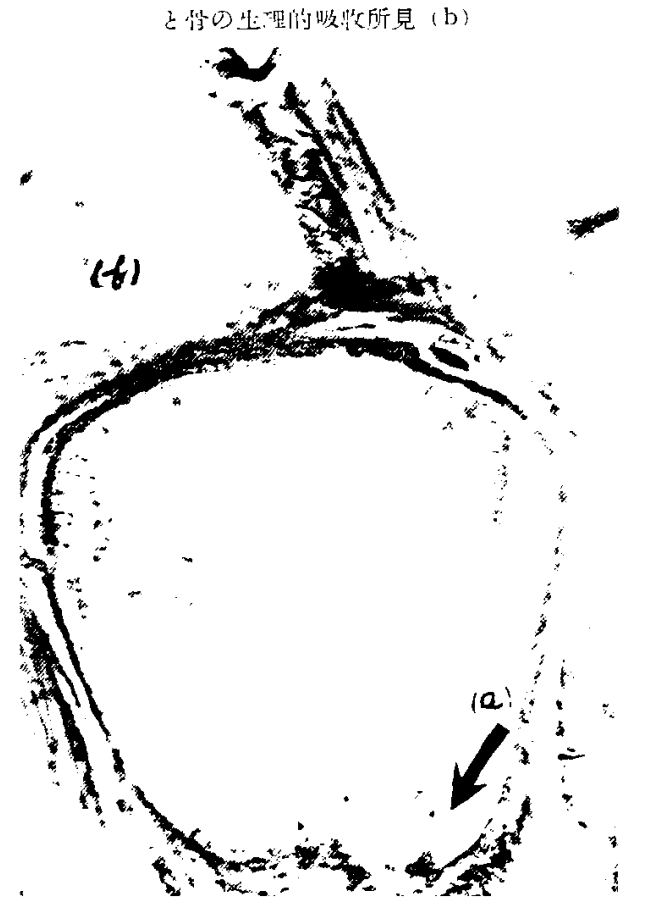

第 2 图 myromatöse Gewebz 攻U中心

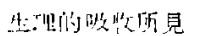

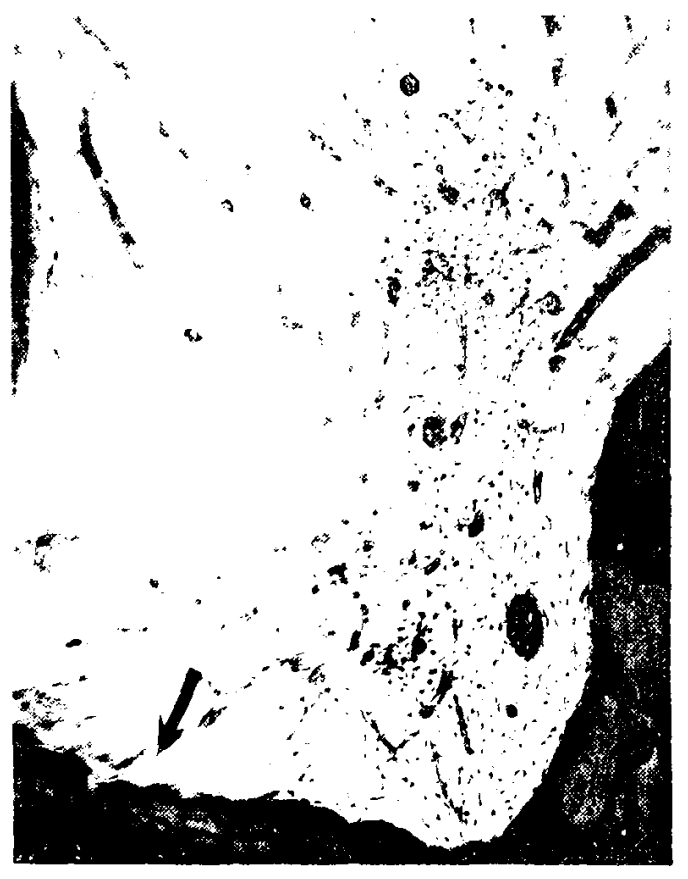

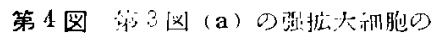

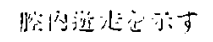

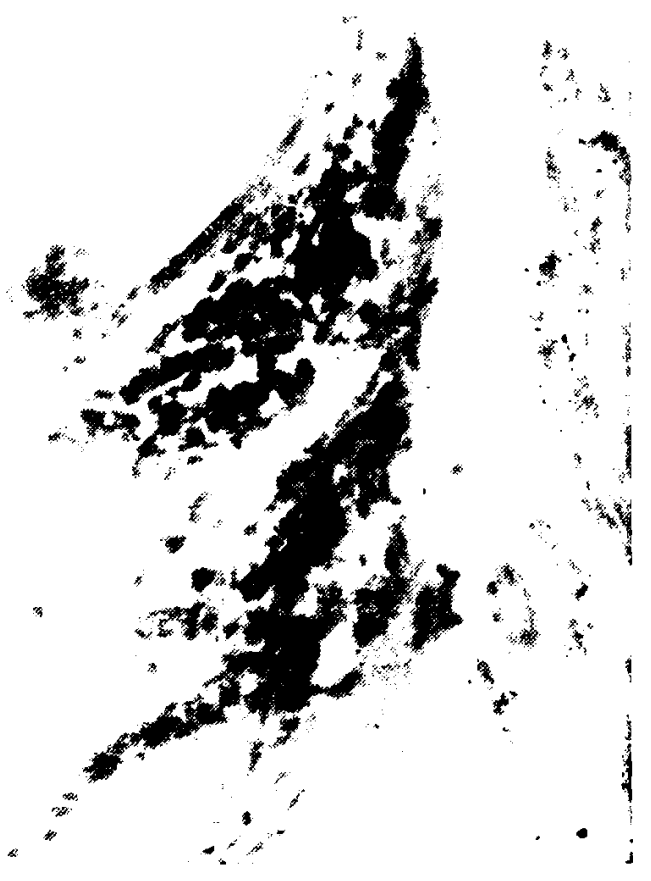

